\title{
Magnesium Doped Hydroxyapatite-Based Coatings Obtained by Pulsed Galvanostatic Electrochemical Deposition with Adjustable Electrochemical Behavior
}

\author{
Diana Maria Vranceanu ${ }^{1}\left(\mathbb{D}\right.$, Ionut Cornel Ionescu ${ }^{1,2, *}$, Elena Ungureanu ${ }^{1}(\mathbb{D}$, \\ Mihai Ovidiu Cojocaru ${ }^{1}$, Alina Vladescu ${ }^{3,4, *}$ and Cosmin Mihai Cotrut ${ }^{1}[$ \\ 1 Faculty of Materials Science and Engineering, University Politehnica of Bucharest, \\ RO060042 Bucharest, Romania; diana.vranceanu@upb.ro (D.M.V.); ungureanu.elena14@yahoo.com (E.U.); \\ cojocarumihaiovidiu@yahoo.co.uk (M.O.C.); cosmin.cotrut@upb.ro (C.M.C.) \\ 2 Faculty of Dental Medicine, University of Medicine and Pharmacy "Carol Davila", \\ RO020021 Bucharest, Romania \\ 3 Department for Advanced Surface Processing and Analysis by Vacuum Technologies, National Institute of \\ Research and Development for Optoelectronics-INOE 2000, RO77125 Magurele, Romania \\ 4 National Research Tomsk Polytechnic University, 634050 Tomsk, Russia \\ * Correspondence: ionescu.ionut.cornel@gmail.com (I.C.I.); alinava@inoe.ro (A.V.); \\ Tel.: +4-021-457-57-59 (A.V.)
}

Received: 25 June 2020; Accepted: 22 July 2020; Published: 24 July 2020

check for updates

\begin{abstract}
The aim of this study was to adapt the electrochemical behavior in synthetic body fluid (SBF) of hydroxyapatite-based coatings obtained by pulsed galvanostatic electrochemical deposition through addition of $\mathrm{Mg}$ in different concentrations. The coatings were obtained by electrochemical deposition in a typical three electrodes electrochemical cell in galvanic pulsed mode. The electrolyte was obtained by subsequently dissolving $\mathrm{Ca}\left(\mathrm{NO}_{3}\right)_{2} \cdot 4 \mathrm{H}_{2} \mathrm{O}, \mathrm{NH}_{4} \mathrm{H}_{2} \mathrm{PO}_{4}$, and $\mathrm{Mg}\left(\mathrm{NO}_{3}\right)_{2} \cdot 6 \mathrm{H}_{2} \mathrm{O}$ in ultra-pure water and the $\mathrm{pH}$ value was set to 5 . The morphology consists of elongated and thin ribbon-like crystals for hydroxyapatite (HAp), which after the addition of $\mathrm{Mg}$ became a little wider. The elemental and phase composition evidenced that HAp was successfully doped with Mg through pulsed galvanostatic electrochemical deposition. The characteristics and properties of hydroxyapatite obtained electrochemically can be controlled by adding $\mathrm{Mg}$ in different concentrations, thus being able to obtain materials with different properties and characteristics. In addition, the addition of $\mathrm{Mg}$ can lead to the control of hydroxyapatite bioactive ceramics in terms of dissolution rate.
\end{abstract}

Keywords: coatings; electrochemical deposition; doped hydroxyapatite; magnesium; electrochemical behavior

\section{Introduction}

Intense and regular use of medical devices has resulted in hostile factors, including wearing out, micro-motions, and increase in corrosion. Thus, the challenges in the medical field are to design implantable materials with tunable properties in terms of bioactivity, biodegradation, and bactericidal effect, but the difficulties are redoubtable since these surfaces' characteristics tend to deteriorate in time.

Recently, the coatings field has attracted much interest and the ideal implant coating will likely be multifunctional, combining different technologies to promote a rapid osseointegration while inhibiting adverse tissue reactions, foreign body response or other events [1-5]. In addition to optimization of mechanical and chemical compatibilities, another important aspect for implant materials is the establishment of a suitable surface state in terms of a tailored surface topography and chemistry 
that stimulates bone cell growth and activates an optimum bone osseointegration [6,7]. To achieve a successful fixation, it is important to create a stable implant-bone interface [1].

To overcome these problems, the main inorganic component in natural bone-hydroxyapatite (HAp, $\mathrm{Ca}_{10}\left(\mathrm{PO}_{4}\right)_{6}(\mathrm{OH})_{2}$ )-is widely used as a bioactive coating material [8-10]. Moreover, it is possible to tailor the properties of HAp-based materials by addition of a wide variety of substitutions and ion doping found in natural bones (e.g., $\mathrm{Mg}, \mathrm{Zn}, \mathrm{Sr}$ ) into its crystal structure [11-20] in search for the promotion of bone remodeling, antibacterial activity, and enhanced bio-integration. It is reasonable to deduce that by incorporation of different ions into HAp coating simultaneously could be beneficial for the improvement of both bioactivity and long-term stability such as biodegradation [21] and electrochemical behavior of the coating in physiological media [22,23].

Hydroxyapatite is a virtually ubiquitous bio-ceramic and is extensively used as a bioactive coating on Ti-based implants due to its chemical and structural similarity to hard tissues, and consequently it can be bound directly to bone. In the HAp structure, the $\mathrm{PO}_{4}{ }^{3-}$ anions can be replaced by carbonate groups while the calcium ions by $\mathrm{Mg}^{2+}, \mathrm{Na}^{+}, \mathrm{K}^{+}$, etc., and trace elements like $\mathrm{Pb}^{2+}, \mathrm{Cu}^{2+}$, and $\mathrm{Fe}^{2+}[24]$.

Magnesium $(\mathrm{Mg})$ is also essential for metabolism, being the fourth most abundant element in the human body. Especially in the medical field, $\mathrm{Mg}$ has gained more and more attention from the scientific community, where it is employed either as a main or alloying element or as a substitution/doping element [25-28]. By doping HAp with $\mathrm{Mg}$, the mineral metabolism can be influenced, modifying the dissolution rate of crystals and the biodegradation of the corresponding materials [29]. Landi et al. [30] showed in an in vivo study that Mg-HAp enhanced osseoconductivity and resorption, compared to commercial HAp. The substitution of $\mathrm{Ca}^{2+}$ by $\mathrm{Mg}^{2+}$ in HAp is limited due to the large size difference between $\mathrm{Mg}^{2+}$ and $\mathrm{Ca}^{2+}(\sim 0.28 \AA$ difference in radius), which leads to strong distortions of the HAp lattice, reducing its crystallinity. These changes have a direct impact on the properties of Mg-HAp, compared to their non-substituted analogues [31], by increasing their solubility. Zhao et al. reported that $\mathrm{Mg} / \mathrm{HAp}$-coated surface promotes osteogenic differentiation of pre-osteoblasts and osseointegration during the early stage of bone healing [32].

Since 1990, the interest in electrochemical deposition (ED) has evolved, getting ascendant attention as a superior method for the preparation of different protective coatings [33,34]. ED is ideal for the deposition of doped HAp coatings [13,18,35-37] due to: (i) the low temperatures involved, which enable formation of highly crystalline deposits with low solubility in body fluids and low residual stresses; (ii) the ability to coat porous and geometrically complex materials; (iii) the possible improvement of the substrate/coating bond strength; and (iv) the ability to control the thickness, composition, and microstructure of the deposit.

The aim of this study is to adapt the electrochemical behavior in synthetic body fluid (SBF) of hydroxyapatite-based coatings through addition of $\mathrm{Mg}$ in different concentrations obtained by pulsed galvanostatic electrochemical deposition. Magnesium was selected because it increases the solubility of HAp and thus, properties, such as the electrochemical behavior can be controlled and/or adjusted with respect to the intended medical applications. Even though indirectly, the electrochemical tests carried out in this study in synthetic body fluid (SBF) at human body temperature can be considered as a prediction tool which can indicate the potential biodegradable behavior of the proposed coatings.

\section{Materials and Methods}

\subsection{Preparation of the Coatings}

Titanium alloy (Ti6Al4V, purchased from Bibus Metals AG, Essen, Germany) discs (20 mm $\times$ $2 \mathrm{~mm}$ ) were used as substrates. One side of each disc was metallographically prepared on silicon carbide paper of different grit $(320 \div 800$ grit). The prepared discs were cleaned with ultra-pure water, ASTM I, and iso-propylic alcohol. Before deposition, the Ti6Al4V discs were sonicated in acetone for $20 \mathrm{~min}$ to remove all residues and grease and cleaned with ultra-pure water. 
The electrolyte used for the coating preparation is presented in Table 1 and was obtained by subsequently dissolving the chemical reagents (Table 2) in ultra-pure water. The $\mathrm{pH}$ was adjusted to 5 by dropwise addition of $1 \mathrm{M} \mathrm{NaOH}$. The electrolyte was de-aerated with $\mathrm{N}_{2}$ for 30 min to minimize the formation of $\mathrm{CaCO}_{3}$ deposits. The temperature was maintained at $75^{\circ} \mathrm{C}$ using a heating plate (KA RCT Basic Safety Control Hotplate/Stirrer and ETS-D6 Temp, IKA, Staufen, Germany) and a magnetic stirrer was used to keep the concentration of the electrolyte uniform during deposition.

Table 1. Chemical composition of the used electrolytes and sample codification.

\begin{tabular}{|c|c|c|c|c|c|}
\hline \multirow{2}{*}{ Coating Type } & \multirow{2}{*}{$\begin{array}{c}\text { Sample } \\
\text { Codification }\end{array}$} & \multicolumn{3}{|c|}{ Chemical Composition (mM) } & \multirow{2}{*}{$\begin{array}{l}\text { Molar Ratio } \\
(\mathrm{Ca}+\mathrm{Mg}) / \mathrm{P}\end{array}$} \\
\hline & & $\mathrm{Ca}\left(\mathrm{NO}_{3}\right)_{2} \cdot 4 \mathrm{H}_{2} \mathrm{O}$ & $\mathrm{NH}_{4} \mathrm{H}_{2} \mathrm{PO}_{4}$ & $\mathrm{Mg}\left(\mathrm{NO}_{3}\right)_{2} \cdot 6 \mathrm{H}_{2} \mathrm{O}$ & \\
\hline HAp & $\mathbf{H}$ & 10.500 & \multirow{4}{*}{6.300} & 0 & \multirow{4}{*}{1.67} \\
\hline \multirow{3}{*}{ HAp with $\mathrm{Mg}$} & $\mathrm{H}-\mathrm{Mg} 1$ & 9.450 & & 1.050 & \\
\hline & $\mathrm{H}-\mathrm{Mg} 1.5$ & 8.925 & & 1.575 & \\
\hline & $\mathrm{H}-\mathrm{Mg} 2$ & 8.400 & & 2.100 & \\
\hline
\end{tabular}

Table 2. Grade and purity of the chemical reagents employed in electrolytes preparation.

\begin{tabular}{cccc}
\hline Chemical Formula & Reagent Grade & Purity & Manufacturer \\
\hline $\mathrm{Ca}\left(\mathrm{NO}_{3}\right)_{2} \cdot 4 \mathrm{H}_{2} \mathrm{O}$ & ACS reagent & $\geq 99.00 \%$ & \\
$\mathrm{NH}_{4} \mathrm{H}_{2} \mathrm{PO}$ & Trace metal basis & $99.99 \%$ & Sigma Aldrich, Munich, Germany \\
$\mathrm{Mg}\left(\mathrm{NO}_{3}\right)_{2} \cdot 6 \mathrm{H}_{2} \mathrm{O}$ & ACS reagent & $99.00 \%$ & \\
$\mathrm{NaOH}$ & ACS reagent & $\geq 98.00 \%$ & \\
\hline
\end{tabular}

Pulsed galvanostatic deposition was carried out in a conventional three electrode electrochemical cell using a multichannel Potentiostat/Galvanostat (Parstat MC, Princeton Applied Research-Ametek, Oak Ridge, TN, USA). The deposition was performed for $40 \mathrm{~min}$ on Ti6Al4V discs in pulsed galvanostatic mode with a constant current density of $-0.85 \mathrm{~mA} / \mathrm{cm}^{2}[12,19,38]$. The activation and relaxation stages were set as follows: $\mathrm{i}_{\mathrm{ON}}=-0.85 \mathrm{~mA} / \mathrm{cm}^{2}$ for $\mathrm{t}_{\mathrm{ON}}=1 \mathrm{~s}$, followed by $\mathrm{i}_{\mathrm{OFF}}=0 \mathrm{~mA} / \mathrm{cm}^{2}$ for $\mathrm{t}_{\mathrm{OFF}}=$ $1 \mathrm{~s}$. After the electrochemical deposition, the samples were removed from the electrolyte and gently rinsed with ultra-pure water and stored in a desiccator. Figure 1 shows a schematic illustration of the electrochemical deposition process and the sample codification.

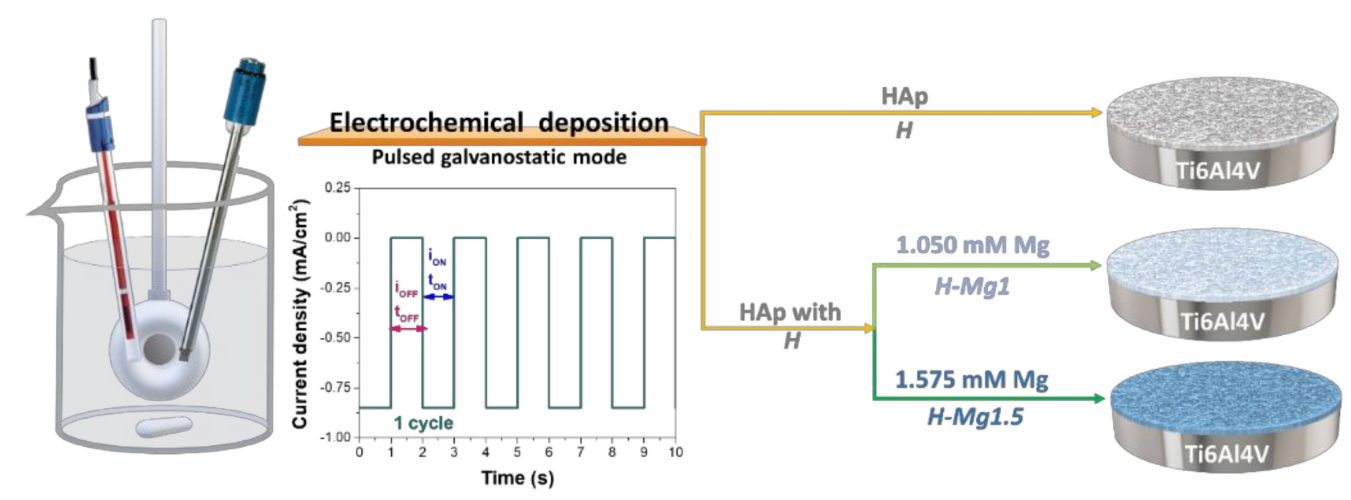

Figure 1. Schematic illustration of the electrochemical deposition process and samples codification.

As a function of $\mathrm{Mg}$ concentration, it was observed that up to $1.5 \mathrm{mM} \mathrm{Mg}\left(\mathrm{NO}_{3}\right)_{2} \cdot 6 \mathrm{H}_{2} \mathrm{O}$ the coatings cover the entire surface exposed to the electrochemical deposition process with a uniform and compact layer which does not present defects. By increasing the $\mathrm{Mg}$ concentration to $2 \mathrm{mM}$, the uniformity and compactness of the coating begins to alter indicating that an increased quantity of $\mathrm{Mg}$ (higher than $1.5 \mathrm{mM}$ ) can lead to a porous, irregular, and heterogenous coating which does not meet 
the minimal criteria selection (for electrochemical investigation) and thus, this coating was not further investigated (H-Mg2).

\subsection{Characterization of Coatings}

The coatings' morphology and elemental composition were investigated by scanning electron microscopy equipped with an X-ray energy dispersive spectrometer (SEM-EDS, Phenom ProX, Phenom World, Eindhoven, Netherlands).

The phase composition of the investigated samples was examined using a SmartLab X-ray diffractometer (Rigaku, city, Japan) with a CuK $\alpha$ radiation $(\lambda=1.5405 \AA)$. Grazing incidence measurements were performed in the $\theta / 2 \theta$ range of $20-60^{\circ}$ with a $0.02^{\circ}$ step, at an incidence angle of $3^{\circ}$. For this purpose, a medium resolution parallel beam optical system was used.

Surface roughness was measured over a length of $4000 \mu \mathrm{m}$ using DEKTAK 150 (Veeco Instruments, Plainview, NY, USA) stylus profilometer. The thickness of the coatings was determined by Dektak 150 stylus profilometer (stylus radius of $12.5 \mu \mathrm{m}$ ), measuring the forming ledge between the deposited film and the uncoated substrate.

The adhesion between the Ti6Al4V substrate and the undoped and doped HAp coatings was measured by performing a "tape test" according to ASTM D3359-17 standard [39] with an Elcometer 107 Cross Hatch Adhesion Tester kit (Ulmer, Aalen, Germany). The test consists of $6 \times 6 \mathrm{~mm}^{2}$ parallel cuts with gaps of $1 \mathrm{~mm}$ between them made with a cutting edge that will generate a lattice pattern. It is important to apply sufficient pressure to ensure that the cutting edge will go through the coating to the substrate's surface. The adhesive tape (ISO/ASTM tape) was placed over the lattice pattern indentation, and after $90 \mathrm{~s}$ the tape was removed by pulling in a single smooth action at angle of $180^{\circ}$ to the coating surface. After the adhesion tests, the coatings were examined by scanning electron microscopy (SEM Phenom Pro X, Phenom World, Eindhoven, Netherlands). The coating adhesion was assessed in terms of area removed by viewing the lattice pattern indentation and was classified in terms of percentages (from highest to weakest): 5B: $0 \%$; $4 \mathrm{~B}: \leq 5 \%$ (not large than 5\%); 3B: $5 \% \div 15 \% ; 2 \mathrm{~B}: 15 \% \div 35 \% ; 1 \mathrm{~B}: 35 \%$ $\div 65 \%$; 0B: $\geq 65 \%$ (larger than $65 \%$ ).

Electrochemical behavior was investigated at $37 \pm 0.5^{\circ} \mathrm{C}$ in synthetic body fluid with a $\mathrm{pH}$ of 7.4 using a PARSTAT 4000 Potentiostat/Galvanostat (Princeton Applied Research, Oak Ridge, TN, USA). The chemical composition of the testing media (SBF) is presented in Table 3 and was made in accordance with the receipt proposed by Kokubo [40]. For electrochemical behavior, an area of $1 \mathrm{~cm}^{2}$ was exposed to the electrolyte (SBF). A typical three-electrode cell with the following set-up: sample as working electrode (WE), a platinum electrode was used as a counter electrode (CE), and saturated calomel (SCE) as reference electrode (RE), was used for all electrochemical measurements. The open circuit potential (OCP) was monitored for $1 \mathrm{~h}$, starting right after the sample's immersion in the electrolyte and the Tafel plots were recorded from -150 (vs. OCP) to $+150 \mathrm{mV}$ (vs. SCE) at a scanning rate of $1 \mathrm{mV} / \mathrm{s}$. All measurements were achieved according to the ASTM G5-94 standard (reapproved 2011) [41]. Experiments were performed in triplicate and the obtained data are presented as mean $\pm \mathrm{SD}$. 
Table 3. Chemical composition and reagents grade and purity used for preparation of synthetic body fluid (SBF) media (1000 mL, $\mathrm{pH}=7.4)$.

\begin{tabular}{cccccc}
\hline No. & $\begin{array}{c}\text { Chemical } \\
\text { Formula }\end{array}$ & Amount & Reagent Grade & Purity & Manufacturer \\
\hline$\# 1$ & $\mathrm{NaCl}$ & $8.035 \mathrm{~g} / \mathrm{L}$ & ACS reagent & $>99.99 \%$ & \\
$\# 2$ & $\mathrm{NaHCO}_{3}$ & $0.355 \mathrm{~g} / \mathrm{L}$ & Bio Reagent & $\geq 99.50 \%$ & \\
$\# 3$ & $\mathrm{KCl}$ & $0.225 \mathrm{~g} / \mathrm{L}$ & Purris p.a. & $\geq 99.50 \%$ & \\
$\# 4$ & $\mathrm{~K}_{2} \mathrm{HPO}_{4} \cdot 3 \mathrm{H}_{2} \mathrm{O}$ & $0.231 \mathrm{~g} / \mathrm{L}$ & Reagent Plus & $\geq 99.00 \%$ & Sigma Aldrich, \\
$\# 5$ & $\mathrm{MgCl}_{2} \cdot 6 \mathrm{H}_{2} \mathrm{O}$ & $0.311 \mathrm{~g} / \mathrm{L}$ & Purum p.a. & $\geq 98.00 \%$ & Munich, Germany \\
$\# 6$ & $\mathrm{HCl}_{\#}$ & $39 \mathrm{~mL}$ & ACS reagent & $\geq 37.00 \%$ & \\
$\# 8$ & $\mathrm{CaCl}_{2}$ & $0.292 \mathrm{~g} / \mathrm{L}$ & ACS reagent & $\geq 99.00 \%$ & \\
$\# 9$ & $\mathrm{Na}_{2} \mathrm{SO}_{4}$ & $0.072 \mathrm{~g} / \mathrm{L}$ & ACS reagent & $\geq 99.00 \%$ & \\
\hline
\end{tabular}

\section{Results and Discussion}

\subsection{Morphology}

The surface morphology and crystallinity of Hap-based coatings are in strong correlation with the current density and the electrolyte ion concentration [13,42]. Nevertheless, the cell performance and biological activity are dependent on the morphology and crystal orientation $[13,43,44]$.

Figure 2 presents the SEM images revealing the morphology of the obtained coatings. As it can be seen, the entire investigated surface has been fully covered regardless of the electrolyte composition with a uniform layer, which also due to its morphology has a high surface to volume ratio. Particularly, for undoped HAp coatings, the morphology consists of elongated and thin ribbon-like crystals which was also reported in other studies $[11,45,46]$.
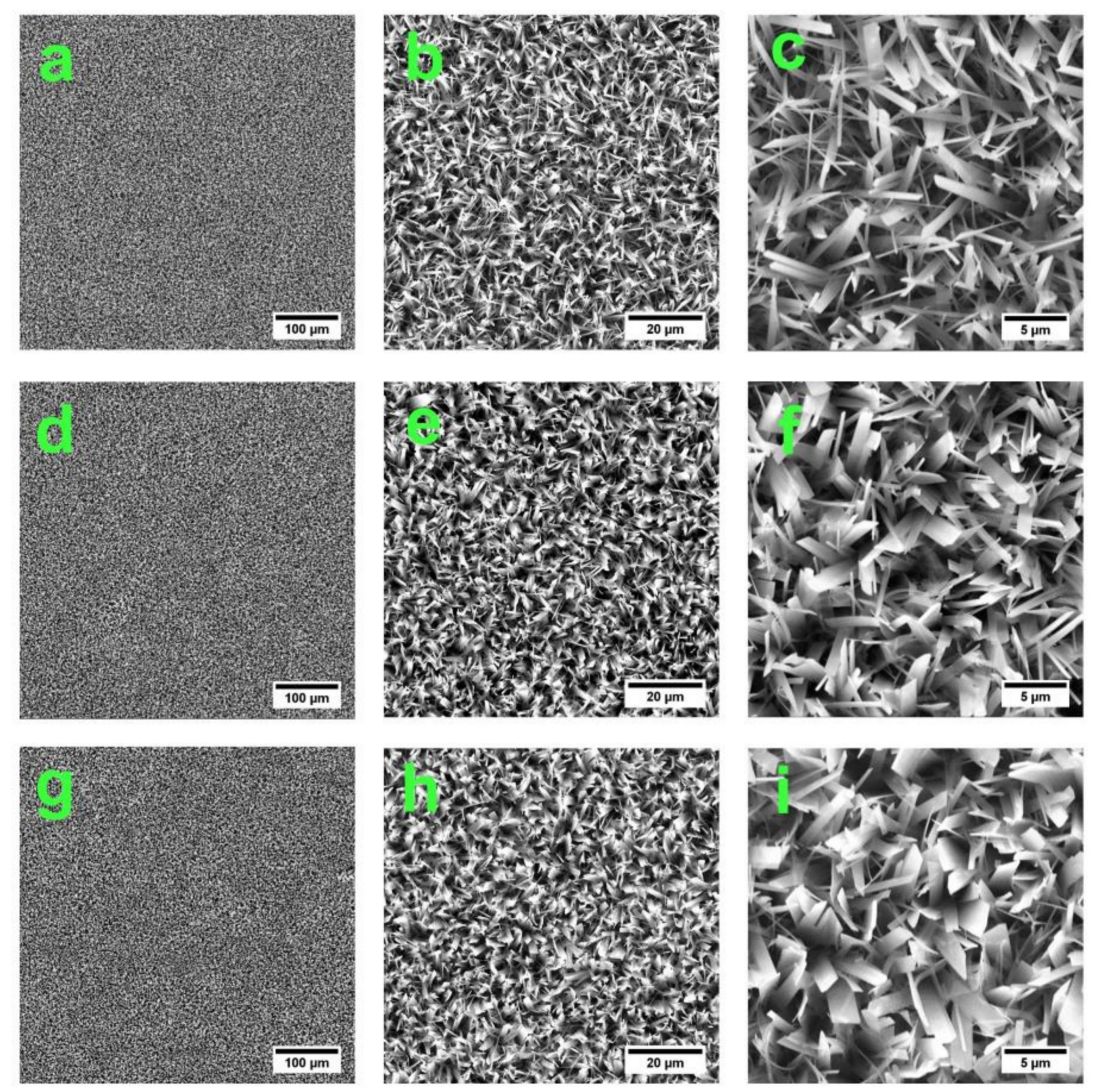

Figure 2. Scanning electron microscopy (SEM) images at different magnifications evidencing the morphology of the $\mathrm{H}(\mathbf{a}-\mathbf{c}), \mathrm{H}-\mathrm{Mg} 1(\mathbf{d}-\mathbf{f})$, and $\mathrm{H}-\mathrm{Mg} 1.5$ (g-i) based coatings. 
At small magnifications it was observed that, regardless of its concentration, the addition of $\mathrm{Mg}$ did not lead to substantial alteration of the ribbon-like morphology, while at higher magnification some dimensional variations were noted. Thus, it can be said that, compared to undoped HAp, Mg addition made the ribbons a little wider. Similar results were also found by Bakin et al. [47].

\subsection{Elemental Composition}

The EDS coatings analysis confirmed the presence of $\mathrm{Mg}$ in the $\mathrm{H}-\mathrm{Mg} 1$ and $\mathrm{H}-\mathrm{Mg} 1.5$ coatings and the presence of $\mathrm{Ca}$ and $\mathrm{P}$ in all coatings. The EDS mapping analysis was used to investigate elemental distribution $(\mathrm{Ca}, \mathrm{P}$, and $\mathrm{Mg})$ and the results are presented in Figure 3.
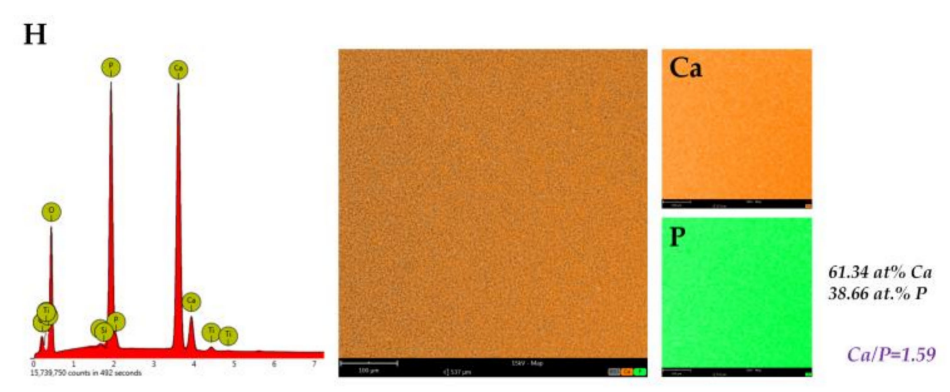

(a)
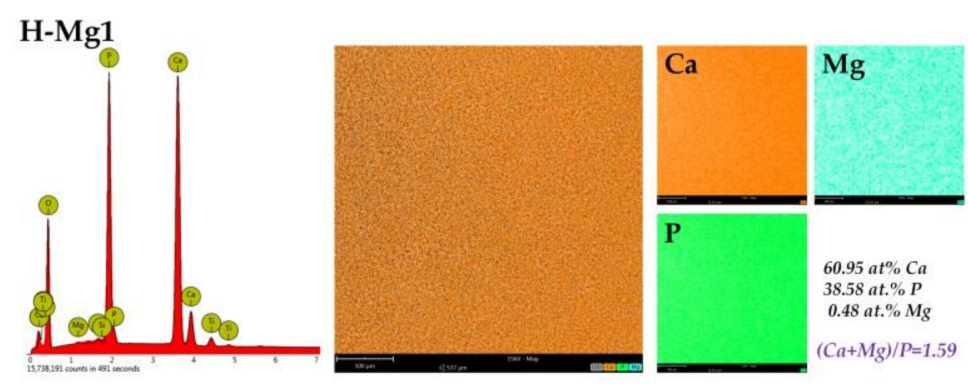

(b)
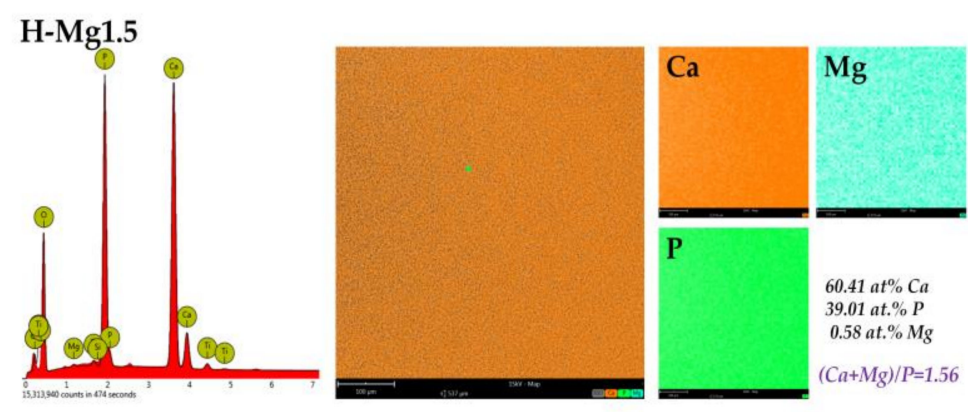

(c)

Figure 3. X-ray energy dispersive spectroscopy (EDS), elemental distribution, and chemical composition of the undoped (a) and Mg-doped hydroxyapatite (Hap) (b,c) based coatings.

According to this investigation, all elements were uniformly distributed in all three types of coatings. The $(\mathrm{Ca}+\mathrm{Mg}) / \mathrm{P}$ ratio is lower than the stoichiometric one (Figure 4), suggesting that the doping process causes Ca-deficient apatite, probably due to the generation of crystal defects from the ion substitution [16]. A ratio of 1.59 was noted for $\mathrm{H}$ and $\mathrm{H}-\mathrm{Mg} 1$ coatings, while for $\mathrm{H}-\mathrm{Mg} 1.5$ the ratio was 1.56. According to some studies [48,49], Ca-deficient apatite is beneficial for bone formation, but further investigations are required. 


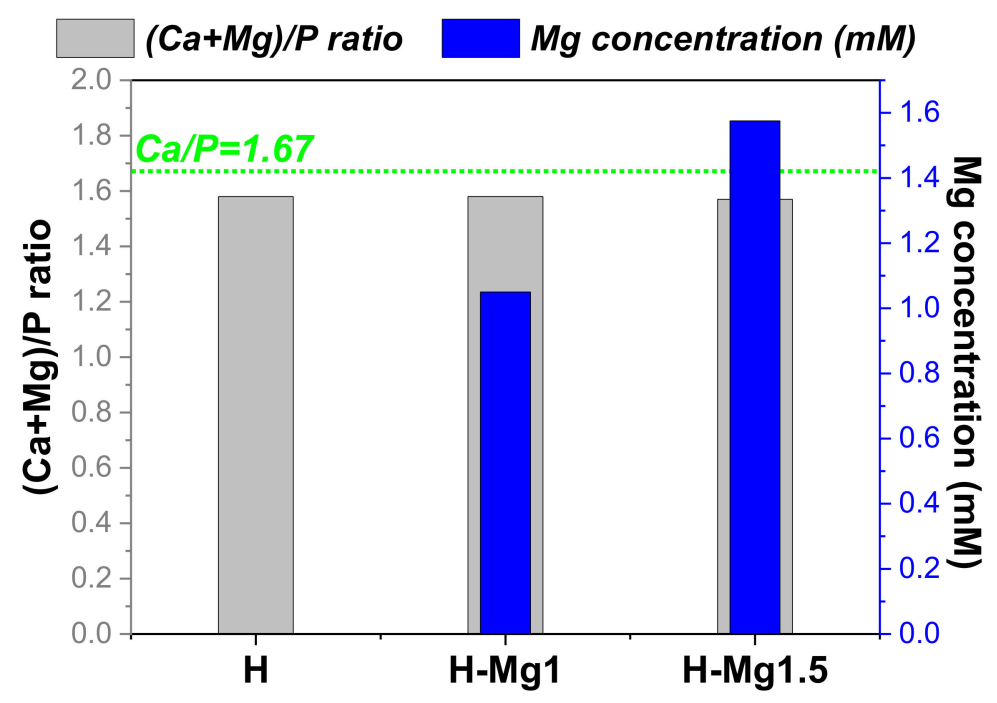

Figure 4. Dependency between $(\mathrm{Ca}+\mathrm{Mg}) / \mathrm{P}$ ratio and the $\mathrm{Mg}$ concentration.

\subsection{Phase Composition}

The X-ray diffractograms of undoped and doped HAp coatings are presented in Figure 5.

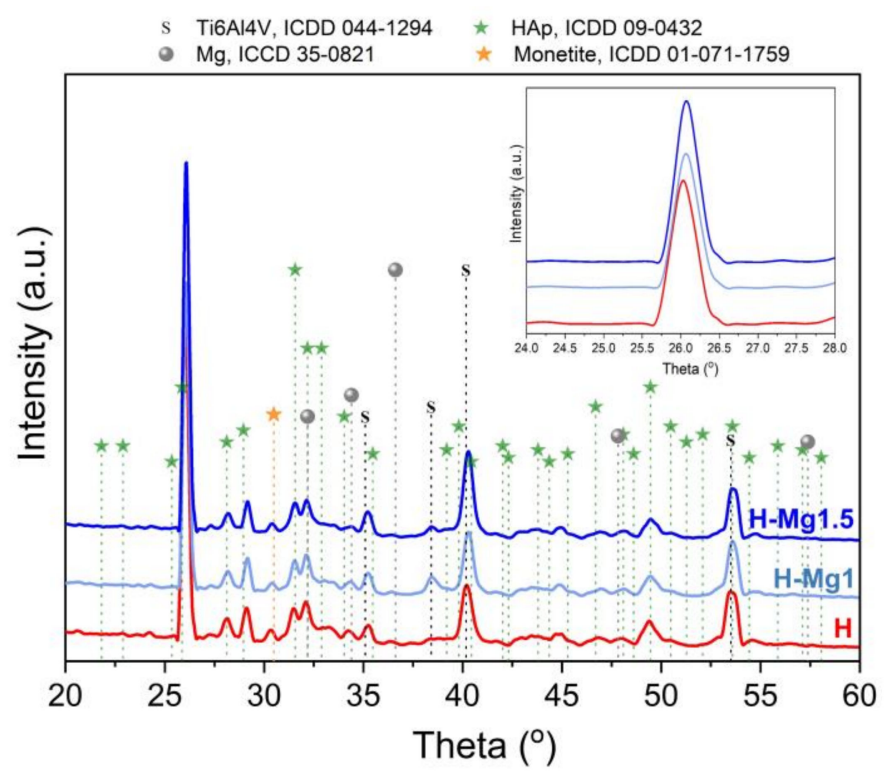

Figure 5. The X-ray diffractograms for undoped and Mg-doped HAp.

All of the coatings showed the characteristic diffraction peaks of HAp (ICDD-The International Centre for Diffraction Data, \#09-0432). Nevertheless, the strongest relative intensity was registered for the plan (002) at $25.95^{\circ}$ which is typical for electrochemical deposition $[36,50,51]$, suggesting that the coatings are grown perpendicular on the Ti6Al4V substrate. According to the literature, oriented HAp may enable control over cells' behavior [52], and in particular the (002) preferred orientation promotes cell adhesion $[53,54]$. All of the coatings present a small peak which was assigned to monetite (ICDD, \#01-071-1759), a precursor of hydroxyapatite. Monetite phase can be converted into hydroxyapatite by alkaline treatment [55,56]. According to the literature [57], besides its ability to regenerate bone, monetite resorbs in vivo faster than other calcium phosphates enabling the implant replacement by a newly formed tissue. 
In the detailed diffractogram from Figure 5, it can be observed that after addition of Mg into HAp, the peak associated with (002) has slightly shifted towards higher angles from $25.95^{\circ}$ registered for $\mathrm{H}$ samples to $26.06^{\circ}$ and $26.10^{\circ}$ for $\mathrm{H}-\mathrm{Mg} 1$ and $\mathrm{H}-\mathrm{Mg} 1.5$, respectively. These findings are in good correlation with other papers $[19,58,59]$ and indicate that $\mathrm{Mg}$ has replaced $\mathrm{Ca}$ in the HAp lattice. This result is consistent with the smaller ionic radius of $\mathrm{Mg}^{2+}$ compared with $\mathrm{Ca}^{2+}(0.69$ and $0.99 \AA$, respectively). No other impurities were detected.

The average crystal size was calculated using the Debye-Scherrer approximation considering the (002) peak. In the literature, it is suggested that this peak should be selected for quantitative estimations because apart from others it does not show interferences [60]. According to our results, the $\mathrm{H}$ coatings has a crystal size of $8.4 \pm 0.1 \mathrm{~nm}$, while the addition of $\mathrm{Mg}$ led to a slight increment of the crystal size reaching a value of $8.8 \pm 0.1$ and $10.2 \pm 0.1 \mathrm{~nm}$ for $\mathrm{H}-\mathrm{Mg} 1$ and $\mathrm{H}-\mathrm{Mg} 1.5$, respectively; the addition of a small amount of $\mathrm{Mg}$ did not significantly affect the crystal size.

In the literature, there are few modalities for quantifying the degree of crystallinity. In this paper, the degree of crystallinity was calculated based on the intensity of (002) reflection peak using the equation reported in previous studies [60-62]. It was found that the crystallinity increases with respect to the $\mathrm{Mg}$ quantity. Thus, compared to $\mathrm{H}$ coatings, which presented a crystallinity of $17.8 \%$, by increasing the $\mathrm{Mg}$ amount the crystallinity reaches a maximum of $29.6 \%$ for $\mathrm{H}-\mathrm{Mg} 1.5$ coating, closely followed by $\mathrm{H}-\mathrm{Mg} 1$ coating which had a value of $27.1 \%$.

Based on the XRD results, it can be concluded that the hydroxyapatite-based coating become more crystalline as a function of $\mathrm{Mg}$ concentration. Usually, both crystallinity degree and crystal size are related with the impurity amount and the stoichiometry $(\mathrm{Ca} / \mathrm{P}$ ratio). Note that for the $\mathrm{H}$ and $\mathrm{H}-\mathrm{Mg} 1$ coatings, the $\mathrm{Ca} / \mathrm{P}$ is similar, while the both $\mathrm{H}-\mathrm{Mg} 1$ and $\mathrm{H}-\mathrm{Mg} 1.5$ exhibited closer $\mathrm{Mg}$ content and probably this is the reason that the crystal size or crystallinity degree has closer values.

\subsection{Roughness}

The coating roughness was carried out by stylus profilometry, and the main results are presented in Table 4. As it can be seen, the average roughness and root mean square roughness parameters have increased after $\mathrm{Mg}$ addition, being also dependent on the quantity which has been added into the electrolyte. Figure 6 presents the representative profiles for each coating. By increasing the $\mathrm{Mg}$ quantity from 1 to $1.5 \mathrm{mM}$, the average roughness has increased $\sim 8$ times, passing from nanometric scale in the case of $\mathrm{H}-\mathrm{Mg} 1$ to micrometric scale for the $\mathrm{H}-\mathrm{Mg} 1.5$ coatings. According to the literature, the average roughness values of the commercial coated dental implants is found to be between 0.1 and $10 \mu \mathrm{m}$ [20]. Thus, it can be noted that the developed coatings are found to be in this limitation.

The skewness parameter offers information regarding the height distribution (skew $<0$ for a surface with deeper valleys, skew $>0$ for a surface with higher peaks) [63]. Thus, it can be noted that all coatings presented positive skewness suggesting that the surface is predominantly with peaks that protrude above the mean line. By comparing the values among them, it is visible that compared to the undoped HAp, the lowest skew was registered for H-Mg1 coatings, suggesting that in this concentration, $\mathrm{Mg}$ reduces the peaks height and the surface tends towards a symmetrical topography, whereas increasing the $\mathrm{Mg}$ content leads to a very high skewness value which suggests that the surface presents very high peaks.

Table 4. Roughness parameters (Ra-average roughness, Rq-root mean square, Skew-skewness) and thickness of the investigated coatings.

\begin{tabular}{ccccc}
\hline Coating & Ra $(\mathbf{n m})$ & Rq $(\mathbf{n m})$ & Skew & Thickness $(\boldsymbol{\mu m})$ \\
\hline H & $439.7( \pm 33.9)$ & $587.9( \pm 66.7)$ & $0.84( \pm 0.1)$ & $11.1( \pm 0.9)$ \\
H-Mg1 & $558.2( \pm 37.9)$ & $710.9( \pm 47.0)$ & $0.38( \pm 0.1)$ & $12.2( \pm 0.7)$ \\
H-Mg1.5 & $4396.9( \pm 895.4)$ & $6609.1( \pm 1071.4)$ & $2.44( \pm 0.25)$ & $10.5( \pm 0.7)$ \\
\hline
\end{tabular}




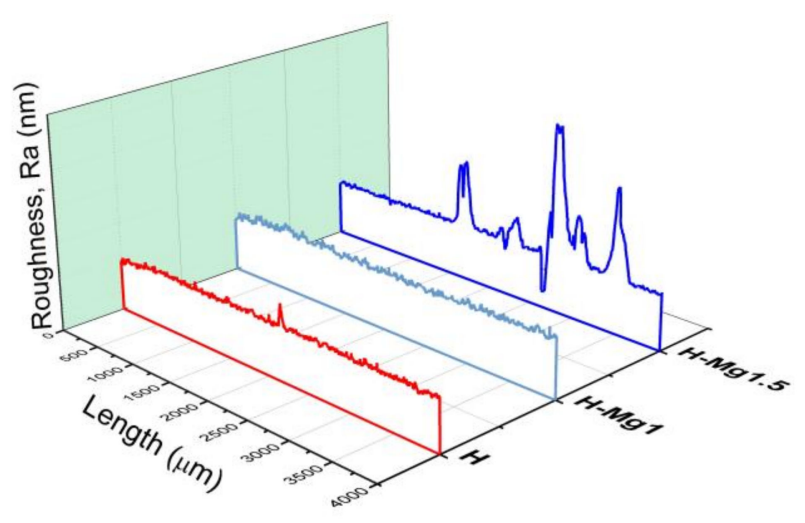

Figure 6. Representative profiles of the obtained coatings.

By measuring the forming ledge between the deposited film and the uncoated substrate, the coating thickness was obtained (Figure 7). Compared to the undoped HAp which has registered a thickness of approximately $11 \mu \mathrm{m}$, the $\mathrm{H}-\mathrm{Mg} 1$ coatings registered an increment, until a value of $\sim 12 \mu \mathrm{m}$, while for the H-Mg1.5, the thickness decreased, reaching the lowest thickness of $10.5 \mu \mathrm{m}$. The thickness differences can be associated with the deposition rate which is influenced by the $\mathrm{Mg}$ quantity added in the electrolyte. Considering that all the parameters involved in the electrochemical deposition were maintained constant, it can be assumed that the quantity of $\mathrm{Mg}$ affects the deposition rate/HAp nucleation and growth. It can be seen that for a small amount of magnesium added $(1 \mathrm{mM})$, the thickness of the HAp layer increases, while after this concentration the thickness decreases. Nevertheless, $\mathrm{Mg}^{2+}$ ions inhibit HAp crystallization, avoiding the formation of large crystals and promoting the formation of more apatite nuclei. Thus, the presence of strong stresses inside the formed layer could be the reason why the HAp coating doped with $2.1 \mathrm{Mm}$ of $\mathrm{Mg}$ is porous, irregular, and heterogenous. This finding can also be correlated with the fact that magnesium can inhibit apatite crystallization [64].

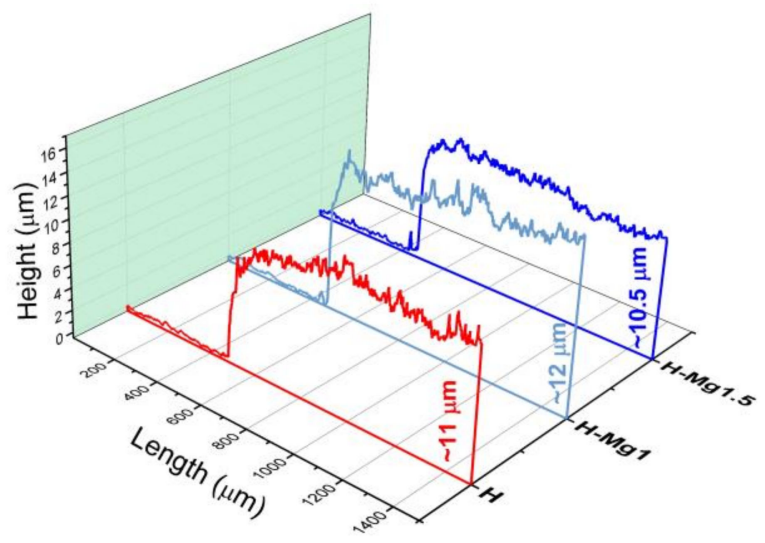

Figure 7. Coating thickness.

\subsection{Adhesion}

Figure 8 depicts the coatings surfaces after adhesion assays by "tape test" according to ASTM procedure. It is worth mentioning that within the adhesive tape removal, from all investigated coatings, a very thin, superficial layer was removed, without affecting the coating structural integrity, leaving behind a very consistent layer of HAp. Similar observations were also made by Parcharoen et al. [65], who investigated the adhesion between HAp-based coatings electrochemically deposited on anodized titania nanotubes of different lengths. 

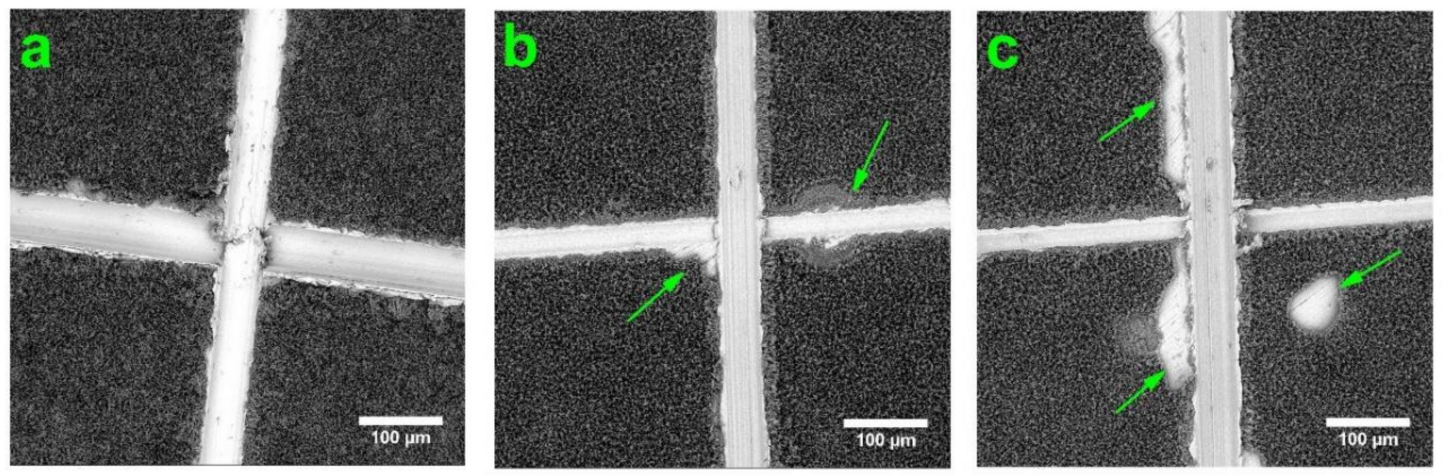

Figure 8. Representative SEM images of $\mathrm{H}$ (a), $\mathrm{H}-\mathrm{Mg} 1$ (b), and $\mathrm{H}-\mathrm{Mg} 1.5$ (c) coatings on Ti6Al4V substrate after the adhesion assay by the "tape test" (green arrow indicating the delaminated/affected areas).

Based on the obtained results after the adhesion assay, it was noted that the coatings codified with $\mathrm{H}$ had the best adhesion to the substrate followed closely by the coatings with $1 \mathrm{mM}$ of $\mathrm{Mg}$ (H-Mg1). These coatings were classified according to ASTM D3359-17 [39] in the following categories: $5 \mathrm{~B}$ for $\mathrm{H}$ coatings because the edges of the cuts were completely smooth with none of the lattice squares detached and $4 \mathrm{~B}$ for $\mathrm{H}-\mathrm{Mg} 1$, where some detachments/flakes, of areas not greater than $5 \%$ at the intersection of the cuts were observed. By increasing the $\mathrm{Mg}$ amount, it was noted that some delamination/detachment were found to be not just at the intersection of the cuts, but also along the cutting line and inside the squares of the lattice, though the affected area is not greater than $35 \%$. Thus, the H-Mg1.5 coatings were classified into a 3B category.

Therefore, it can be concluded that even though after the adhesion assay most of the coating remained on the substrate on all of investigated samples, by increasing the Mg amount, the adhesion begins to weaken. Accordingly, the best results were obtained for $\mathrm{H}$ and $\mathrm{H}-\mathrm{Mg} 1$ coatings, indicating that for a higher concentration of $\mathrm{Mg}(1.5 \mathrm{mM})$ the substrate may require some surface modification treatment before deposition to enhance the bonding strength at the coating-substrate interface.

\subsection{Electrochemical Behaviour}

Coating synthesis on titanium-based substrate enhances the biomineralization ability and acts as protection barrier against ions (especially $\mathrm{Al}$ and $\mathrm{V}$ ) that can be released from the substrate improving the overall in vivo behavior and features [66]. The electrochemical techniques are a very important and useful tool in predicting a material's behavior in vivo by analyzing the reactions at the coating-substrate interface. Figure 9 presents the open circuit potential curves and the Tafel plots of the undoped and Mg-doped coatings deposited on Ti6Al4V substrate for only one set of samples.

The polarization resistance $(R \mathrm{p})$ was calculated by using the Stern-Geary equation:

$$
R_{p}=\frac{1}{2.3 \cdot i_{\text {corr }}} \cdot \frac{\beta_{a} \cdot\left|\beta_{c}\right|}{\beta_{a}+\left|\beta_{c}\right|}
$$

where $R \mathrm{p}$ is the polarization resistance, $\beta_{\mathrm{a}}$ and $\beta_{\mathrm{c}}$ are the anodic and cathodic Tafel slops respectively, and $i_{\text {corr }}$ is the corrosion current density.

Based on Tafel extrapolation the main electrochemical parameters were extracted and presented in Table 5. 


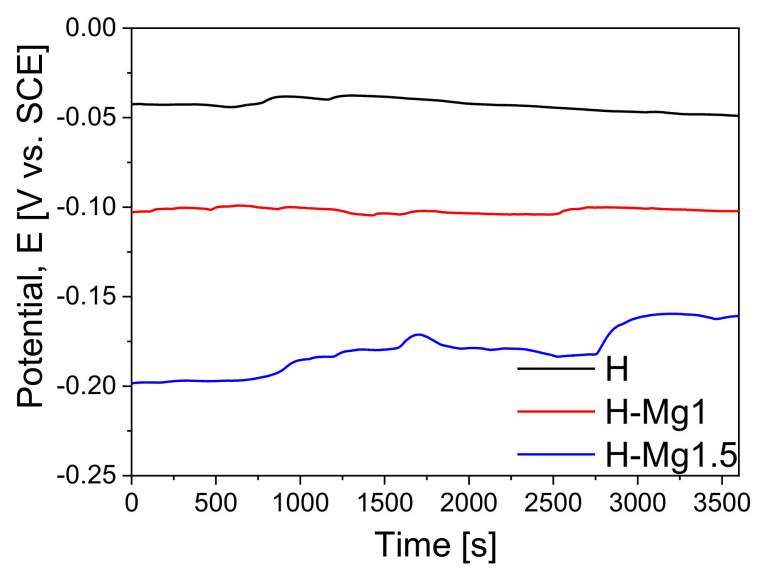

(a)

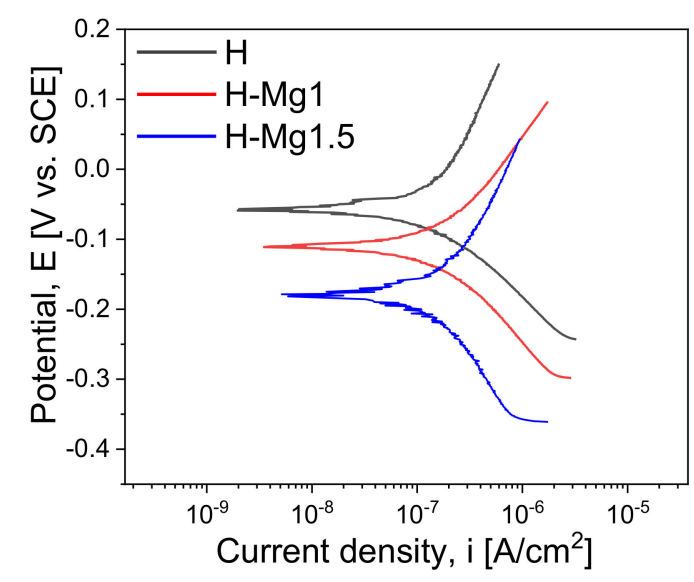

(b)

Figure 9. Open circuit potential curves (a) and Tafel plots (b) of the investigated coatings.

Table 5. Electrochemical parameters of the investigated samples ( $E_{\mathrm{OC}}$-open circuit potential; $E_{\text {corr-corrosion potential; }} i_{\text {corr-corrosion current density; }} R_{\mathrm{p}}$-polarization resistance).

\begin{tabular}{|c|c|c|c|c|c|c|}
\hline Sample & $E_{\mathrm{oc}}(\mathrm{mV})$ & $E_{\text {corr }}(\mathrm{mV})$ & $\begin{array}{c}i_{\text {corr }} \\
\left(\mathrm{nA} / \mathrm{cm}^{2}\right)\end{array}$ & $B c(m V)$ & $\beta \mathrm{a}(\mathrm{mV})$ & $R_{\mathrm{p}}\left(\mathrm{k} \Omega \cdot \mathrm{cm}^{2}\right)$ \\
\hline $\mathrm{H}$ & $-48.9( \pm 5.2)$ & $-56.9( \pm 6.3)$ & $22.45( \pm 3.82)$ & $34.23( \pm 5.51)$ & $35.98( \pm 6.15)$ & $339.70( \pm 10.42)$ \\
\hline H-Mg1 & $-102.2( \pm 7.8)$ & $-110.3( \pm 9.1)$ & $53.70( \pm 4.56)$ & $63.22( \pm 9.47)$ & $60.67( \pm 8.77)$ & $250.67( \pm 11.13)$ \\
\hline H-Mg1.5 & $-160.7( \pm 9.4)$ & $-180.5( \pm 10.7)$ & $90.43( \pm 6.75)$ & $100.33( \pm 12.34)$ & $105.39( \pm 11.92)$ & $247.11( \pm 12.58)$ \\
\hline
\end{tabular}

It is known that a material is resistant to the corrosive attack if it has an electropositive $E_{\text {corr, }}$, low $i_{\text {corr }}$, and high $R_{\mathrm{p}}$ [67]. If we take into consideration the corrosion potential ( $E_{\text {corr }}$ ), it was noted that the most electropositive value was registered for $\mathrm{H}$ coatings, followed by $\mathrm{H}-\mathrm{Mg} 1$ and $\mathrm{H}-\mathrm{Mg} 1.5$, suggesting that by increasing the $\mathrm{Mg}$ content the coatings' resistance to the corrosive attack of the media is poorer. Considering the corrosion current density $\left(i_{\text {corr }}\right)$, the smallest value was registered also for $\mathrm{H}$ coatings, followed by $\mathrm{H}-\mathrm{Mg} 1$ and $\mathrm{H}-\mathrm{Mg} 1.5$ and indirectly suggesting that by adding $\mathrm{Mg}$, the solubility of HAp can increase. Based on the values obtained for anodic $\left(\beta_{\mathrm{a}}\right)$ and cathodic $\left(\beta_{\mathrm{c}}\right)$ Tafel slops of each investigated coating it can be said that the kinetics related to the electron transfer and the number and nature of electrons involved in the two reactions are also similar, indicating a mixed controlled. If we consider the obtained polarization resistance values, it was observed that the highest $R_{\mathrm{p}}$ was obtained for $\mathrm{H}$ followed by $\mathrm{H}-\mathrm{Mg} 1$ and $\mathrm{H}-\mathrm{Mg} 1.5$ coatings, suggesting the order of dissolution/biodegradability as well.

The present study highlights that the addition of $\mathrm{Mg}$ tailors the electrochemical behavior and so, the solubility/biodegradability of HAp. Overall, the findings are in good correlation with a study performed by Cai et al. [68], in which they found that the by increasing the Mg content a higher dissolution rate can be obtained due to the incorporation of Mg into HAp.

\section{Conclusions}

In this study, $\mathrm{Mg}$ in different concentrations was incorporated in HAp structure by electrochemical deposition method using galvanic pulses technique on Ti6Al4V substrate. All coatings presented a morphology consisting of ribbon-like crystals.

Compared with undoped HAp coatings, the ribbon-like crystals appear to increase their dimension as a function of $\mathrm{Mg}$ concentration added in the electrolyte. The coatings were preferentially oriented in the (002) direction which is typical for electrochemical deposition and after addition of $\mathrm{Mg}$ some small shift towards higher angles were noted indicating that the substitution occurred in the HAp lattice. Furthermore, Mg addition led to a higher degree of crystallinity and crystal size, compared to undoped 
HAp. The $(\mathrm{Ca}+\mathrm{Mg}) / \mathrm{P}$ ratio was 1.59 for $\mathrm{H}$ and $\mathrm{H}-\mathrm{Mg} 1$ and 1.56 for $\mathrm{H}-\mathrm{Mg} 1.5$, suggesting that by increasing the $\mathrm{Mg}$ amount, the ratios tend towards lower values. Adhesion assays evidenced that a concentration of $1.5 \mathrm{mM}$ of $\mathrm{Mg}$ in the electrolyte leads to a weaker adhesion, while using just $1 \mathrm{mM}$ the adhesion is closer to the undoped HAp-based coatings. The electrochemical behavior highlighted that undoped HAp presented the most electropositive corrosion potential and the highest polarization resistance. By comparing the coatings with $\mathrm{Mg}$ addition, it was observed that the $\mathrm{H}-\mathrm{Mg} 1.5$ coatings presented the highest corrosion current density and the lowest polarization resistance suggesting the weakest electrochemical behavior in SBF media. Thus, it can be observed that by doping with $\mathrm{Mg}$ the electrochemically deposited HAp, the electrochemical behavior can be tuned and so, the dissolution rate as well.

In conclusion, the properties and characteristics of HAp obtained by electrochemical deposition can be controlled through addition of $\mathrm{Mg}$ in different concentrations, thus obtaining biomaterials with tunable properties suitable for medical applications.

Author Contributions: Conceptualization and methodology, C.M.C. and D.M.V.; investigation, E.U., I.C.I., and A.V.; data analysis and interpretation, D.M.V., A.V., and C.M.C.; writing-original draft preparation, I.C.I., C.M.C., and D.M.V.; writing-review and editing, D.M.V., M.O.C., A.V., and C.M.C. All authors have read and agreed to the published version of the manuscript.

Funding: This research has been funded by the Operational Program Human Capital of the Ministry of European Funds through the Financial Agreement 51668/09.07.2019, SMIS code 124705; by grants of the Romanian Ministry of Research and Innovation, CCCDI-UEFISCDI, projects number COFUND-ERANET-RUS-PLUS-CoatDegraBac no.68/2018 as well the Core Program of 2019 (no. 18N/2019). The XRD investigations were performed using the systems modernized by the PROINSTITUTIO Project-contract No. 19PFE/17.10.2018.

Conflicts of Interest: The authors declare no conflicts of interest.

\section{References}

1. Goodman, S.B.; Yao, Z.; Keeney, M.; Yang, F. The future of biologic coatings for orthopaedic implants. Biomaterials 2013, 34, 3174-3183. [CrossRef]

2. Surmenev, R.A.; Surmeneva, M.A.; Ivanova, A.A. Significance of calcium phosphate coatings for the enhancement of new bone osteogenesis-A review. Acta Biomater. 2014, 10, 557-579. [CrossRef]

3. Raphel, J.; Holodniy, M.; Goodman, S.B.; Heilshorn, S.C. Multifunctional coatings to simultaneously promote osseointegration and prevent infection of orthopaedic implants. Biomaterials 2016, 84, 301-314. [CrossRef] [PubMed]

4. Canillas, M.; Pena, P.; de Aza, A.H.; Rodríguez, M.A. Calcium phosphates for biomedical applications. Boletín Soc. Española Cerámica Vidr. 2017, 56, 91-112. [CrossRef]

5. Furko, M.; Havasi, V.; Kónya, Z.; Grünewald, A.; Detsch, R.; Boccaccini, A.R.; Balázsi, C. Development and characterization of multi-element doped hydroxyapatite bioceramic coatings on metallic implants for orthopedic applications. Bol. La Soc. Esp. Ceram. Y Vidr. 2018, 57, 55-65. [CrossRef]

6. Damiati, L.; Eales, M.G.; Nobbs, A.H.; Su, B.; Tsimbouri, P.M.; Salmeron-Sanchez, M.; Dalby, M.J. Impact of surface topography and coating on osteogenesis and bacterial attachment on titanium implants. J. Tissue Eng. 2018, 9, 1-19. [CrossRef]

7. Souza, J.C.M.; Sordi, M.B.; Kanazawa, M.; Ravindran, S.; Henriques, B.; Silva, F.S.; Aparicio, C.; Cooper, L.F. Nano-scale modification of titanium implant surfaces to enhance osseointegration. Acta Biomater. 2019, 94, 112-131. [CrossRef] [PubMed]

8. Mitran, V.; Ion, R.; Miculescu, F.; Necula, M.; Mocanu, A.-C.; Stan, G.; Antoniac, I.; Cimpean, A. Osteoblast Cell Response to Naturally Derived Calcium Phosphate-Based Materials. Materials 2018, 11, 1097. [CrossRef]

9. Dascalu, C.-A.; Miculescu, F.; Mocanu, A.-C.; Constantinescu, A.E.; Butte, T.M.; Pandele, A.M.; Ciocoiu, R.-C.; Voicu, S.I.; Ciocan, L.T. Novel Synthesis of Core-Shell Biomaterials from Polymeric Filaments with a Bioceramic Coating for Biomedical Applications. Coatings 2020, 10, 283. [CrossRef]

10. Miculescu, F.; Mocanu, A.C.; Stan, G.E.; Miculescu, M.; Maidaniuc, A.; Cîmpean, A.; Mitran, V.; Voicu, S.I.; Machedon-Pisu, T.; Ciocan, L.T. Influence of the modulated two-step synthesis of biogenic hydroxyapatite on biomimetic products' surface. Appl. Surf. Sci. 2018, 438, 147-157. [CrossRef] 
11. Bhattacharjee, A.; Gupta, A.; Verma, M.; Anand, M.P.; Sengupta, P.; Saravanan, M.; Manna, I.; Balani, K. Antibacterial and magnetic response of site-specific cobalt incorporated hydroxyapatite. Ceram. Int. 2020, 46, 513-522. [CrossRef]

12. Thanh, T.T.; Cotrut, C.M.; Vranceanu, M.D.; Ungureanu, E.; Tarcolea, M. Studies of microstructure and composition of modified hydroxyapatite coatings via SEM investigations. U.P.B. Sci. Bull. Ser. B 2020, 82, 145-154.

13. Huang, Y.; Hao, M.; Nian, X.; Qiao, H.; Zhang, X.; Zhang, X.; Song, G.; Guo, J.; Pang, X.; Zhang, H. Strontium and copper co-substituted hydroxyapatite-based coatings with improved antibacterial activity and cytocompatibility fabricated by electrodeposition. Ceram. Int. 2016, 42, 11876-11888. [CrossRef]

14. Li, T.; Ling, L.; Lin, M.; Peng, H.; Ren, H.; Lou, C.-W.; Lin, J.-H. Recent advances in multifunctional hydroxyapatite coating by electrochemical deposition. J. Mater. Sci. 2020, 55, 6352-6374. [CrossRef]

15. Sharma, M.; Nagar, R.; Meena, V.K.; Singh, S. Electro-deposition of bactericidal and corrosion-resistant hydroxyapatite nanoslabs. RSC Adv. 2019, 9, 11170-11178. [CrossRef]

16. Munirathinam, B.; Jaladurgam, N.R.; Magesh, J.; Narayanan, R.; Mol, J.M.C.; Neelakantan, L. Improved corrosion protection of titanium implant material by crystallographic texturing of Sr doped calcium phosphate electrodeposits. Thin Solid Films 2019, 675, 115-121. [CrossRef]

17. Morejón-Alonso, L.; Mochales, C.; Nascimento, L.; Müller, W. Electrochemical deposition of Sr and $\mathrm{Sr} / \mathrm{Mg}$-co-substituted hydroxyapatite on Ti-40Nb alloy. Mater. Lett. 2019, 248, 65-68. [CrossRef]

18. Huang, Y.; Song, G.; Chang, X.; Wang, Z.; Zhang, X.; Han, S.; Su, Z.; Yang, H.; Yang, D.; Zhang, X. Nanostructured Ag+-substituted fluorhydroxyapatite- $\mathrm{TiO}_{2}$ coatings for enhanced bactericidal effects and osteoinductivity of Ti for biomedical applications. Int. J. Nanomed. 2018, 13, 2665-2684. [CrossRef]

19. Vranceanu, D.M.; Tran, T.; Ungureanu, E.; Negoiescu, V.; Tarcolea, M.; Dinu, M.; Vladescu, A.; Zamfir, R.; Timotin, A.C.; Cotrut, C.M. Pulsed electrochemical deposition of Ag doped hydroxyapatite bioactive coatings on Ti6Al4V for medical purposes. UPB Sci. Bull. Ser. B Chem. Mater. Sci. 2018, 80, 173-184.

20. Yajing, Y.; Qiongqiong, D.; Yong, H.; Han, S.; Pang, X. Magnesium substituted hydroxyapatite coating on titanium with nanotublar $\mathrm{TiO}_{2}$ intermediate layer via electrochemical deposition. Appl. Surf. Sci. 2014, 305, 77-85. [CrossRef]

21. Lin, W.-C.; Chuang, C.-C.; Wang, P.-T.; Tang, C.-M. A Comparative Study on the Direct and Pulsed Current Electrodeposition of Cobalt-Substituted Hydroxyapatite for Magnetic Resonance Imaging Application. Materials 2018, 12, 116. [CrossRef] [PubMed]

22. Vranceanu, D.M.; Parau, A.C.; Cotrut, C.M.; Kiss, A.E.; Constantin, L.R.; Braic, V.; Vladescu, A. In vitro evaluation of Ag doped hydroxyapatite coatings in acellular media. Ceram. Int. 2019, 45, 11050-11061. [CrossRef]

23. Vlădescu, A.; Pârâu, A.; Pană, I.; Cotruț, C.M.; Constantin, L.R.; Braic, V.; Vrânceanu, D.M. In Vitro Activity Assays of Sputtered HAp Coatings with SiC Addition in Various Simulated Biological Fluids. Coatings 2019, 9, 389. [CrossRef]

24. Ergun, C.; Webster, T.J.; Bizios, R.; Doremus, R.H. Hydroxylapatite with substituted magnesium, zinc, cadmium, and yttrium. I. Structure and microstructure. J. Biomed. Mater. Res. 2002, 59, 305-311. [CrossRef]

25. Antoniac, I.; Miculescu, F.; Cotrut, C.; Ficai, A.; Rau, J.V.; Grosu, E.; Antoniac, A.; Tecu, C.; Cristescu, I. Controlling the Degradation Rate of Biodegradable Mg-Zn-Mn Alloys for Orthopedic Applications by Electrophoretic Deposition of Hydroxyapatite Coating. Materials 2020, 13, 263. [CrossRef]

26. Antoniac, I.; Popescu, D.; Zapciu, A.; Antoniac, A.; Miculescu, F.; Moldovan, H. Magnesium Filled Polylactic Acid (PLA) Material for Filament Based 3D Printing. Materials 2019, 12, 719. [CrossRef]

27. Vladescu, A.; Mihai Cotrut, C.; Ak Azem, F.; Bramowicz, M.; Pana, I.; Braic, V.; Birlik, I.; Kiss, A.; Braic, M.; Abdulgader, R.; et al. Sputtered Si and Mg doped hydroxyapatite for biomedical applications. Biomed. Mater. 2018, 13, 025011. [CrossRef]

28. Rau, J.V.; Antoniac, I.; Filipescu, M.; Cotrut, C.; Fosca, M.; Nistor, L.C.; Birjega, R.; Dinescu, M. Hydroxyapatite coatings on $\mathrm{Mg}-\mathrm{Ca}$ alloy prepared by Pulsed Laser Deposition: Properties and corrosion resistance in Simulated Body Fluid. Ceram. Int. 2018, 44, 16678-16687. [CrossRef]

29. Bertinetti, L.; Drouet, C.; Combes, C.; Rey, C.; Tampieri, A.; Coluccia, S.; Martra, G. Surface characteristics of nanocrystalline apatites: Effect of $\mathrm{Mg}$ surface enrichment on morphology, surface hydration species, and cationic environments. Langmuir 2009, 25, 5647-5654. [CrossRef] 
30. Landi, E.; Logroscino, G.; Proietti, L.; Tampieri, A.; Sandri, M.; Sprio, S. Biomimetic Mg-substituted hydroxyapatite: From synthesis to in vivo behaviour. J. Mater. Sci. Mater. Med. 2008, 19, 239-247. [CrossRef]

31. Chen, W.; Liu, Y.; Courtney, H.S.; Bettenga, M.; Agrawal, C.M.; Bumgardner, J.D.; Ong, J.L. In vitro anti-bacterial and biological properties of magnetron co-sputtered silver-containing hydroxyapatite coating. Biomaterials 2006, 27, 5512-5517. [CrossRef]

32. Zhao, S.; Jiang, Q.; Peel, S.; Wang, X.; He, F. Effects of magnesium-substituted nanohydroxyapatite coating on implant osseointegration. Clin. Oral Implant. Res. 2013, 24, 34-41. [CrossRef] [PubMed]

33. Bucur, A.I.; Linul, E.; Taranu, B.-O. Hydroxyapatite coatings on Ti substrates by simultaneous precipitation and electrodeposition. Appl. Surf. Sci. 2020, 527, 146820. [CrossRef]

34. Dorozhkin, S.V. Calcium orthophosphate deposits: Preparation, properties and biomedical applications. Mater. Sci. Eng. C 2015, 55, 272-326. [CrossRef]

35. Eliaz, N.; Sridh, T.M. Electrocrystallization of hydroxyapatite and its dependence on solution conditions. Cryst. Growth Des. 2008, 8, 3965-3977. [CrossRef]

36. Cotrut, C.M.; Vladescu, A.; Dinu, M.; Vranceanu, D.M. Influence of deposition temperature on the properties of hydroxyapatite obtained by electrochemical assisted deposition. Ceram. Int. 2017, 44, 669-677. [CrossRef]

37. Vladescu, A.; Vranceanu, D.M.; Kulesza, S.; Ivanov, A.N.; Bramowicz, M.; Fedonnikov, A.S.; Braic, M.; Norkin, I.A.; Koptyug, A.; Kurtukova, M.O.; et al. Influence of the electrolyte's pH on the properties of electrochemically deposited hydroxyapatite coating on additively manufactured Ti64 alloy. Sci. Rep. 2017, 7. [CrossRef]

38. Oriň, R.; Oriň, A.; Kupková, M.; Hrubovčáková, M.; Škantárová, L.; Arlinghaus, H.F. Study of Electrochemical Deposition and Degradation of Hydroxyapatite Coated Iron Biomaterials. Int. J. Electrochem. Sci. 2015, 10, 659-670.

39. ASTM International. Standard Test Methods for Rating Adhesion by Tape Test; ASTM D3359-17; ASTM International: West Conshohocken, PA, USA, 2017; pp. 1-9.

40. Kokubo, T.; Takadama, H. How useful is SBF in predicting in vivo bone bioactivity? Biomaterials 2006, 27, 2907-2915. [CrossRef]

41. ASTM International. Standard Reference Test Method for Making Potentiostatic and Potentiodynamic Anodic Polarization Measurements; ASTM G5-94(2011)e1; ASTM International: West Conshohocken, PA, USA, 2011.

42. Li, T.-T.; Ling, L.; Lin, M.-C.; Jiang, Q.; Lin, Q.; Lou, C.-W.; Lin, J.-H. Effects of ultrasonic treatment and current density on the properties of hydroxyapatite coating via electrodeposition and its in vitro biomineralization behavior. Mater. Sci. Eng. C 2019, 105, 110062. [CrossRef]

43. Chakraborty, R.; Seesala, V.S.; Sengupta, S.; Dhara, S.; Saha, P.; Das, K.; Das, S. Comparison of Osteoconduction, cytocompatibility and corrosion protection performance of hydroxyapatite-calcium hydrogen phosphate composite coating synthesized in-situ through pulsed electro-deposition with varying amount of phase and crystallinity. Surf. Interfaces 2018, 10, 1-10. [CrossRef]

44. Huang, Y.; Zhou, G.; Zheng, L.; Liu, H.; Niu, X.; Fan, Y. Micro-/Nano- sized hydroxyapatite directs differentiation of rat bone marrow derived mesenchymal stem cells towards an osteoblast lineage. Nanoscale 2012, 4, 2484. [CrossRef] [PubMed]

45. Wang, H.; Eliaz, N.; Xiang, Z.; Hsu, H.P.; Spector, M.; Hobbs, L.W. Early bone apposition in vivo on plasma-sprayed and electrochemically deposited hydroxyapatite coatings on titanium alloy. Biomaterials 2006, 27, 4192-4203. [CrossRef]

46. Kanamoto, K.; Imamura, K.; Kataoka, N.; Oshitani, J.; Imanaka, H.; Nakanishi, K. Formation characteristics of calcium phosphate deposits on a metal surface by $\mathrm{H} 2 \mathrm{O} 2$-electrolysis reaction under various conditions. Colloids Surf. A Physicochem. Eng. Asp. 2009, 350, 79-86. [CrossRef]

47. Bakin, B.; Koc Delice, T.; Tiric, U.; Birlik, I.; Ak Azem, F. Bioactivity and corrosion properties of magnesium-substituted CaP coatings produced via electrochemical deposition. Surf. Coatings Technol. 2016, 301, 29-35. [CrossRef]

48. Biemond, J.E.; Hannink, G.; Jurrius, A.M.G.; Verdonschot, N.; Buma, P. In Vivo Assessment of Bone Ingrowth Potential of Three-Dimensional E-Beam Produced Implant Surfaces and the Effect of Additional Treatment by Acid Etching and Hydroxyapatite Coating. J. Biomater. Appl. 2012, 26, 861-875. [CrossRef]

49. Šponer, P.; Strnadová, M.; Urban, K. In vivo behaviour of low-temperature calcium-deficient hydroxyapatite: Comparison with deproteinised bovine bone. Int. Orthop. 2011, 35, 1553-1560. [CrossRef] 
50. Thanh, D.T.M.; Nam, P.T.; Phuong, N.T.; Que, L.X.; Van Anh, N.; Hoang, T.; Lam, T.D. Controlling the electrodeposition, morphology and structure of hydroxyapatite coating on 316L stainless steel. Mater. Sci. Eng. C 2013, 33, 2037-2045. [CrossRef]

51. Li, T.-T.; Ling, L.; Lin, M.-C.; Jiang, Q.; Lin, Q.; Lin, J.-H.; Lou, C.-W. Properties and Mechanism of Hydroxyapatite Coating Prepared by Electrodeposition on a Braid for Biodegradable Bone Scaffolds. Nanomaterials 2019, 9, 679. [CrossRef]

52. Dong, X.-L.; Zhou, H.-L.; Wu, T.; Wang, Q. Behavior Regulation of Adsorbed Proteins via Hydroxyapatite Surface Texture Control. J. Phys. Chem. B 2008, 112, 4751-4759. [CrossRef]

53. Liu, X.; He, D.; Zhou, Z.; Wang, G.; Wang, Z.; Wu, X.; Tan, Z. Characteristics of (002) Oriented Hydroxyapatite Coatings Deposited by Atmospheric Plasma Spraying. Coatings 2018, 8, 258. [CrossRef]

54. Kim, H.; Camata, R.P.; Lee, S.; Rohrer, G.S.; Rollett, A.D.; Hennessy, K.M.; Bellis, S.L.; Vohra, Y.K. Calcium Phosphate Bioceramics with Tailored Crystallographic Texture for Controlling Cell Adhesion. MRS Proc. 2006, 925. [CrossRef]

55. Zou, Z.; Liu, X.; Chen, L.; Lin, K.; Chang, J. Dental enamel-like hydroxyapatite transformed directly from monetite. J. Mater. Chem. 2012, 22, 22637. [CrossRef]

56. Mišković-Stanković, V.B. Electrophoretic Deposition of Ceramic Coatings on Metal Surfaces. In Electrodeposition and Surface Finishing: Fundamentals and Applications; Stojan, S.D., Ed.; Springer: New York, NY, USA, 2014; pp. 133-216. ISBN 978-1-4939-4830-7.

57. Tamimi, F.; Le Nihouannen, D.; Eimar, H.; Sheikh, Z.; Komarova, S.; Barralet, J. The effect of autoclaving on the physical and biological properties of dicalcium phosphate dihydrate bioceramics: Brushite vs. monetite. Acta Biomater. 2012, 8, 3161-3169. [CrossRef] [PubMed]

58. Batra, U.; Kapoor, S.; Sharma, S. Influence of Magnesium Ion Substitution on Structural and Thermal Behavior of Nanodimensional Hydroxyapatite. J. Mater. Eng. Perform. 2013, 22, 1798-1806. [CrossRef]

59. Gopi, D.; Karthika, A.; Nithiya, S.; Kavitha, L. In vitro biological performance of minerals substituted hydroxyapatite coating by pulsed electrodeposition method. Mater. Chem. Phys. 2014, 144, 75-85. [CrossRef]

60. Rusu, V.M.; Ng, C.H.; Wilke, M.; Tiersch, B.; Fratzl, P.; Peter, M.G. Size-controlled hydroxyapatite nanoparticles as self-organized organic-inorganic composite materials. Biomaterials 2005, 26, 5414-5426. [CrossRef]

61. Landi, E.; Tampieri, A.; Celotti, G.; Sprio, S. Densification behaviour and mechanisms of synthetic hydroxyapatites. J. Eur. Ceram. Soc. 2000, 20, 2377-2387. [CrossRef]

62. Poralan, G.M.; Gambe, J.E.; Alcantara, E.M.; Vequizo, R.M. X-ray diffraction and infrared spectroscopy analyses on the crystallinity of engineered biological hydroxyapatite for medical application. IOP Conf. Ser. Mater. Sci. Eng. 2015, 79, 012028. [CrossRef]

63. Leach, R. Surface Topography Characterisation. In Fundamental Principles of Engineering Nanometrology; Elsevier: Amsterdam, The Netherlands, 2014; pp. 241-294.

64. Mayer, I.; Schlam, R.; Featherstone, J.D. Magnesium-containing carbonate apatites. J. Inorg. Biochem. 1997, 66, 1-6. [CrossRef]

65. Parcharoen, Y.; Kajitvichyanukul, P.; Sirivisoot, S.; Termsuksawad, P. Hydroxyapatite electrodeposition on anodized titanium nanotubes for orthopedic applications. Appl. Surf. Sci. 2014, 311, 54-61. [CrossRef]

66. Zhang, Z.; Dunn, M.F.; Xiao, T.D.; Tomsia, A.P.; Saiz, E. Nanostructured Hydroxyapatite Coatings for Improved Adhesion and Corrosion Resistance for Medical Implants. MRS Proc. 2001, 703. [CrossRef]

67. Baboian, R.; Scully, J.R.; Dean, S.W.J. Corrosion Tests and Standards; Fontana, M.G., Staehle, R.W., Eds.; Springer US Plenum Press: New York, NY, USA, 2005; Volume 6, ISBN 978-1-4684-8988-0.

68. Cai, Y.; Zhang, S.; Zeng, X.; Wang, Y.; Qian, M.; Weng, W. Improvement of bioactivity with magnesium and fluorine ions incorporated hydroxyapatite coatings via sol-gel deposition on Ti6Al4V alloys. Thin Solid Films 2009, 517, 5347-5351. [CrossRef]

(C) 2020 by the authors. Licensee MDPI, Basel, Switzerland. This article is an open access article distributed under the terms and conditions of the Creative Commons Attribution (CC BY) license (http://creativecommons.org/licenses/by/4.0/). 